\title{
PENGEMBANGAN VIDEO PEMBELAJARAN OPEN STREET MAP UNTUK PEMBUATAN PETA DIGITAL FORMAT SHAPEFILE MENGGUNAKAN SPATIAL MANAGER
}

\author{
Illham Marsudi ${ }^{1}$, Febtri Yanna Ramadani ${ }^{2}$, Sunar Rochmadi ${ }^{3}$, Nuryadin Eko Raharjo ${ }^{4}$, dan Nur Hidayat ${ }^{5}$ \\ 1,2,3,4,5 Pendidikan Teknik Sipil dan Perencanaan, FT, UNY \\ Email: $\underline{\text { ilham @uny.ac.id }}$
}

\begin{abstract}
ABSTRAK
Tujuan penelitian ini adalah mengembangkan video pembelajaran OpenStreetMap untuk pembuatanpeta digital format shapefile menggunakan Spatial Manager. Penelitian ini termasuk dalam jenis penelitian pengembangan (Res earch and Development/R\&D) y ang mengacu pada model pengembangan $4 \mathrm{D}$ (Define,Design, Development, and Dis seminate) oleh Thiagarajan. Teknik pengumpulan data menggun akan angketyang diberikan kepada ahli materi, ahli media, dan pengguna (mahas is wa). Teknik analis is data menggunakan teknik analisis deskriptif kuantitatif. Hasil penelitian dan pengembang an media pembelajaran memperoleh kesimpulan sebagai berikut:(1) Tahap define menghasilkan kebutuhan pembelajaran tentang OpenStreetMap untukpembuatanpeta digital format shapefile menggunakan Spatial Manager; (2) Tahap design menghasilkan flowchart,storyboard,dan take video yang sesuai serta produk y ang dihasilkan berupa video pembelajaran deng an teknikanimasidanscreen record berformat *.mp4 yang dapat diputardi komputer/laptop maupun smartphone standar, berdurasiselama 15 menit 50 detik, dan ukuran file sebesar 56,7 MB; (3) Tahap development menghasilkan penilaiantingkatkelayakan media video pembelajaran y ang dikembangkan berdas arkan penilaian oleh ahli materi adalah $90,91 \%$ termasuk dalam kategori "layak", sedangkan penilaian oleh ahlimedia adalah 91,13\% termasuk dalamkategori "layak", dan penilaian pengguna (mahasiswa) adalah $86,62 \%$ termasuk dalam kategori "layak"; (4) Tahap dis seminate merupakan penyebarluasan hasil penelitian berupa produk video y ang diunggah melalui platform Youtubedan memberikan file kepada pengguna.
\end{abstract}

Kata kunci: Open Street Map, Penelitian dan Pengembangan, Shapefile, Spatial Manager

\section{ABSTRACT}

The purpose of this study was to develop an OpenStreetMap learning video for mak ing shapefileformat digital maps using the Spatial Manager. This research is included in the type ofdevelopment research(Research and Development $/ R \& D$ ) which refers to the $4 D$ development model (Define, Design, Development, and Disseminate) by Thiagarajan. The data collection technique uses a questionnairegiventomaterialexperts,media experts, and users (students). The data analysis technique used quantitative descriptiveanalysistechniques. The results of research and development of instructional media obtained the following conclusions:(1)Thedefine stage resulted in learning needs about OpenStreetMap for making shapefile formatdigitalmapsusing theSpatial Manager; (2) The design stage produces appropriate flowcharts, storyboards, and takevideosandtheresulting product is a learning video with animation techniques and screen record in *.mp 4 formatthatcanbeplayedon a standard computer/laptop or smartphone, with a duration of 15 minutes 50 seconds, andafilesizeof $56.7 \mathrm{MB}$; (3) The development stage produces an assessment of the feasibility level of the instructional video media developed based on the assessment by material experts is $90.91 \%$ included in the "feasible" category, whilethe assessment by media experts is $91.13 \%$ included in the "feasible" category, and the assessmentusers(students) are $86.62 \%$ in the "decent" category; (4) The disseminate stage is the disseminationofresearchresultsintheform of video products uploaded via the Youtube platform and providing files to users.

Keywords: Open Street Map, Research and Development, Shapefile, Spatial Manager

PENDAHULUAN

Pesatnya pertambahan perguruan tinggi semakin berdampak pada kondisi persaingan dalam merebut pangsa pasar yang semakin ketat. Data dari Badan Pusat Statistik (BPS, 2019) mencatat tingkat pengangguran terbuka (TPT) selama 
Februari 2017 hingga Februari 2019 secara umum mengalami penurunan, tetapi jika dilihat secara agregat tingkat lulusan diploma dan sarjana naik sebesar $8,5 \%$ dan 25\%. Berdasarkan infografik Katadata (2019), menyebutkan beberapa penyebab naiknya tingkat pengangguran lulusan diploma dan sarjana antara lain: (1) keterampilan yang tidak sesuai dengan kebutuhan dunia usaha/dunia industri; (2) ekspetasi akan penghasilkan dan status lebih tinggi; dan (3) penyedia lapangan pekerjaan terbatas.

Jurusan Pendidikan Teknik Sipil dan Perencanaan (JPTSP) Fakultas Teknik (FT) Universitas Negeri Yogyakarta (UNY) merupakan salah satu lembaga pendidikan yang mempersiapkan tenaga kerja dalam bidang ketekniksipilan. Di JPTSP FT UNY salah satu mata kuliah yang erat kaitannya dengan persaingan tenaga kerja dan teknologi adalah Praktikum Geomatika II. Topik utama yang dipelajari dalam mata kuliah Praktikum Geomatika II ini adalah survei dan pemetaan yang selalu diperlukan dalam proses pembangunan terutama bangunan fisik. Pekerjaan survei dan pemetaan dilakukan untuk memperoleh data dan informasi spasial yang pada umumnya disajikan dalam bentuk peta. Pekerjaan ini mencangkup tiga tahap yaitu tahap pengumpulan data, tahap pengolahan data dan informasi, serta tahap penyajian data dan informasi.

Semakin berkembangnya teknologi muncul alat-alat baru dan teknologi baru yang dapat digunakan untuk melakukan pekerjaan survei dan pemetaan, mulai dari pemetaan fotogrametri, pemetaan terestris hingga pemetaan dengan digital. Seiring dengan pesatnya perkembangan perangkat lunak dan perangkat keras peta digital adalah representasi fenomena geografik yang disimpan untuk ditampilkan dan dianalisis oleh komputer digital (Nuryadin, 2005:19).

Menurut Rochmadi dan Hidayat (2020), pada mata kuliah Praktikum Geomatika II terdapat beberapa kompetensi yang harus dikuasai oleh mahasiswa salah satunya adalah penggunaan alat yang mengikuti perkembangan zaman dan pembuatan peta digital. Seiring berjalannya waktu, proses pembuatan peta digital yang awalnya mengandalkan citra satelit sebagai bahan utamanya berubah menjadi peta berbasis web yaitu OpenStreetMap (OSM) tahun 2004 oleh Steve Coast. Karena OSM bersifat terbuka (open source) dan bebas maka perkembangannya sangat pesat (HOT, 2015). Hal terbukti dengan banyaknya relawan yang ikut berpartisipasi dalam mengembangkannya. Bahkan sampai saat ini banyak perusahaan perangkat lunak yang memanfaatkan OSM. Salah satu perusahaan tersebut adalah Spatial Manager (www.spatialmanager.com) yang dikembangkan oleh sekelompok profesional yang bekerja di bidang Sistem Informasi Geografis (SIG), Perencanaan, Infrastruktur, dan Teknik Sipil. Spatial Manager adalah aplikasi yang dirancang untuk mengelola data spasial dengan cara yang sederhana, cepat, dan murah. Kelebihan menggunakan OSM sebagai bahan utama dalam proses pembuatannya adalah tidak melalui proses digitasi tetapi melalui ekstraksi sehingga dapat dijadikan peta digital format shapefile.

Kesulitan mahasiswa terlihat ketika melakukan praktik. Permasalahan yang muncul dalam pembelajaran adalah penyampaian materi tidak sepenuhnya dapat dipahami mahasiswa karena kurangnya media yang membantu memperjelas materi dari dosen sehingga ketika melaksanakan praktik mahasiswa akan kebingungan. Berdasarkan silabus mata kuliah Praktikum 
Geomatika II, mahasiswa dtuntut untuk menguasai 8 kompetensi dasar dalam satu semester atau 16 kali pertemuan. Selain itu dalam proses ekstraksi, masing-masing perangkat lunak yang digunakan dapat menghasilkan data spasial yang berbedabeda serta proses yang dilakukan saat mengubah peta digital menjadi format shapefile juga berbeda. Salah satu solusi alternatifnya adalah pembuatan media pembelajaran sesuai dengan kenyataan atau real view sehingga dapat lebih efektif dan efisien untuk meningkatkan kompetensi mahasiswa pada kebutuhan tenaga terampil surveyor di industri.

Media audio-visual berupa video merupakan salah satu sarana alternatif dalam melakukan proses pembelajaran berbasis teknologi. Video dinyatakan efektif dalam proses pembelajaran berdasarkan skala interval keefektifan untuk skor posttest mencapai skor 79 yang dikategorikan sebagai E atau efektif (Muhariati dkk, 2017). Audio-visual pembelajaran berbasis teknologi dapat digunakan sebagai alternatif dalam mengoptimalkan proses pembelajaran, dikarenakan beberapa aspek antara lain: (1) mudah dikemas dalam proses pembelajaran; (2) lebih menarik untuk pembelajaran; dan (3) dapat diedit (diperbaiki) setiap saat (Umarella dkk, 2018). Selain itu, media video juga dapat digunakan oleh mahasiswa secara mandiri.

\section{METODE}

Jenis Penelitian yang digunakan adalah metode penelitian dan pengembangan atau Research and Development (R\&D) yang mengacu pada model pengembangan 4D (four-D) yang dikemukakan oleh Thiagarajan. Penelitian ini meliputi empat tahapan (Thiagarajan,
1974), yaitu: tahap pendefinisian (define), tahap perancangan (design), tahap pengembangan (develop), dan tahap penyebaran (disseminate).

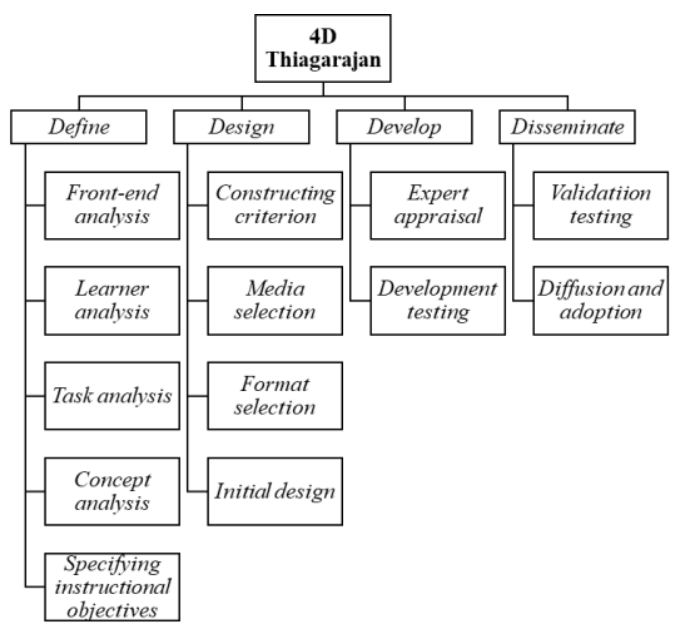

Gambar 1. Prosedur Pengembang an 4D Thiagrajan (Thiagrajan, 1974)

Prosedur penelitian dan pengembangan ini memiliki empat tahapan (Gambar 1), yaitu: a) define, pada tahap pertama melakukan analisis kebutuhan dari media yang akan dikembangkan, diantaranya adalah analisis kebutuhan dosen dan mahasiswa untuk proses pembelajaran, analisis karakteristik mahasiswa terhadap media pembelajaran, dan analisis kurikulum yang ada, serta analisis konsep dan tujuan pembelajaran; b) design, tahap kedua adalah merancang media agar sesuai dengan kebutuhan, yaitu merancang susunan materi, merancang storyboard, dan merancang tampilan media; c) develop, tahap ketiga adalah proses pengembangan, pada proses ini media pembelajaran berupa video yang sudah jadi dilakukan uji kelayakan oleh para ahli dan pengguna (mahasiswa) dengan memberikan angket validasi, kemudian peneliti merevisi video sesuai dengan masukkan dan saran oleh para ahli; d) disseminate, pada tahap terkahir ini media yang sudah dinyatakan layak dan telah 
dilakukan pengujian selanjutnya disebarkan melalui Youtube dan memberikan file kepada pengguna untuk proses pembelajaran.

Teknik analisis data yang dilakukan pada uji kelayakan media adalah teknik analisis data deskriptif kuantitatif yang diperoleh dari uji kelayakan oleh para ahli dan uji coba pengguna. Menurut Arikunto (1993) dalam Hananta dan Sukardi (2018), data kuantitatif adalah berupa angka-angka hasil perhitungan atau pengukuran diproses dengan cara dijumlah kemudian dibandingkan dengan jumlah yang diharapkan sehingga diperoleh persentase kelayakan. Penelitian deskriptif kuantitatif adalah penelitian dengan perolehan data dari sampel populasi penelitian yang akan dianalisis dengan metode statistik kemudian diinterpretasikan.

Alat ukur dalam penelitian ini berupa angket dengan skala pengukuran adalah skala likert 1-4 pada Tabel 1.

Tabel 1. Likert Skala Empat

\begin{tabular}{cc}
\hline Skor & Skala Jawaban \\
\hline 1 & Tidak Sesuai \\
\hline 2 & Kurang Sesuai \\
\hline 3 & Cukup Sesuai \\
\hline 4 & Sesuai \\
\hline
\end{tabular}

Menghitung hasil presentase kelayakan dari para ahli.

Persentase validasi $(\%)=\frac{\text { Skor yang diperoleh }}{\text { Skor Maksimum }} \times 100 \%$

Table 2. Skala Presentase Kelayakan

\begin{tabular}{cc}
\hline Persentase Penilaian & Interpretasi \\
\hline $0-25 \%$ & Tidak Layak \\
\hline $26-50 \%$ & Kurang Layak \\
\hline $51-75 \%$ & Cukup Layak \\
\hline $76-100 \%$ & Layak \\
\hline
\end{tabular}

Menghitung skor rata-rata tiap aspek untuk responden pengguna dengan jumlah 30 mahasiswa.

$$
\text { Skor rata }- \text { rata }(\overline{\mathrm{X}})=\frac{1}{\text { Banyak validator }} \mathrm{x} \frac{\sum \mathrm{x}}{\mathrm{n}}
$$

Keterangan:

$\mathrm{X}=$ Rata-rata perolehan skor

$\Sigma \mathrm{X}=$ Jumlah skor yang diperoleh

$\mathrm{n}=$ Banyaknya butir pertanyaan

Tabel 3. Konversi Skor pada Skala Empat

\begin{tabular}{clc}
\hline No. & \multicolumn{1}{c}{ Interval Nilai } & Kategori \\
\hline 1. & $\mathbf{X} \geq \mathrm{Xi}+1,5 \mathrm{Sdi}$ & Layak \\
\hline 2. & $\mathrm{Xi}<\mathbf{X} \leq \mathrm{Xi}+1,5 \mathrm{Sdi}$ & Cukup Layak \\
\hline 3. & $\mathrm{Xi}-1,5 \mathrm{Sdi}<\mathbf{X} \leq \mathrm{Xi}$ & Kurang Layak \\
\hline 4. & $\mathbf{X} \leq \mathrm{Xi}-1,5 \mathrm{Sdi}$ & Tidak layak \\
\hline
\end{tabular}

Keterangan:

$\mathrm{X}$ : Skor yang dicapai

$\mathrm{Xi}$ (Mean ideal) $: \frac{1}{2} \mathrm{x}$ (skor maksimal + skor minimal)

Sdi (Simpangan Baku Ideal) : $\frac{1}{6} \mathrm{x}$ (skor maksimal - skor minimal)

Data yang diperoleh dari pengguna kemudian direrata mengacu pada Tabel 4.

Tabel 4. Kategori Rerata Skor Jawaban

\begin{tabular}{cc}
\hline Rerata Skor Jawaban & Kategori \\
\hline$X \geq 3,25$ & Layak \\
\hline $3,25 \geq X>2,5$ & Cukup Layak \\
\hline $2,5 \geq X>1,75$ & Kurang Layak \\
\hline$X \leq 1,75$ & Tidak Layak \\
\hline
\end{tabular}

\section{HASIL DAN PEMBAHASAN}

Penelitian dan pengembangan ini adalah menghasilkan media pembelajaran berupa video tentang OpenStreetMap untuk pembuatan peta digital format shapefile menggunakan Spatial Manager yang sesuai dengan alur model pengembangan 4D. Tahap define, menghasilkan kebutuhan pembelajaran berupa silabus, perumusan tujuan pembelajaran, kajian materi Praktikum Geomatika II, perangkat pembuat media, dan penggunaan media. Tahap design ini terkumpul materi yang kemudian didesain dalam media pembelajaran berbasis 
video pembuatan peta digital OpenStreetMap format shapefile menggunakan aplikasi Spatial Manager. Dalam media disesuaikan dengan kondisi kelas, perancangan media pembelajaran yang meliputi: flowchart, storyboard, penataan materi dalam media yang terdiri dari tata letak (layout) yang digunakan, pembuatan skenario pembelajaran, penyusunan materi; dan divisualisasikan dengan penggunaan video. Format video adalah *.mp4 dengan durasi waktu 15 menit 50 detik dan ukuran file sebesar 56,7 MB. Tahap develop, menghasilkan penilaian terhadap tingkat kelayakan produk media pembelajaran yang dikembangkan. Hasil analisis penelitian oleh ahli materi ditampilkan pada Gambar 2.

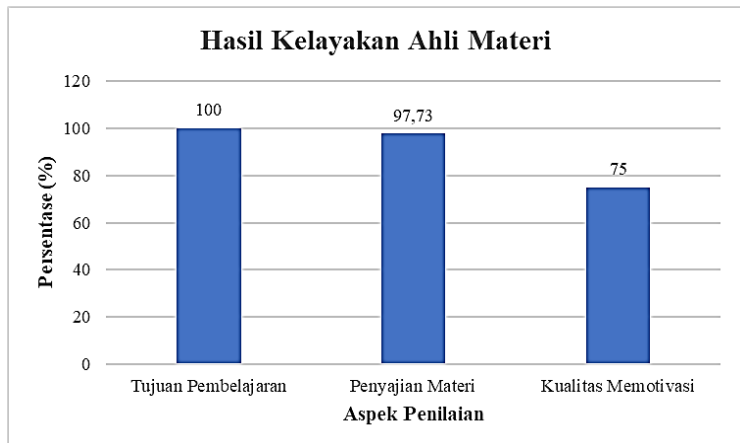

Gambar 2. Diagram Batang Hasil Kelayakan Ahli Materi

Dari diagram batang hasil kelayakan ahli materi (Gambar 2) dapat dijelaskan bahwa persentase hasil kelayakan oleh ahli materi sebesar $100 \%$ untuk aspek tujuan pembelajaran, 97,73 \% untuk aspek penyajian materi, dan $75 \%$ untuk aspek kualitas memotivasi. Dari ketiga aspek diperoleh hasil akhir kelayakan materi sebesar 90,91 \% dengan kategori "Layak". Hasil analisis penelitian oleh ahli media ditampilkan pada Gambar 3.

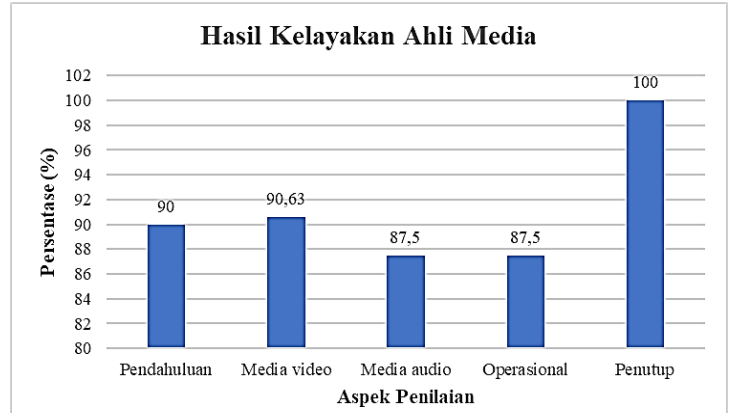

Gambar 3. Diagram batang Hasil Kelayakan Ahli Media

Dari diagram batang hasil kelayakan ahli media (Gambar 3) dapat dijelaskan bahwa persentase hasil kelayakan oleh ahli media sebesar $90 \%$ untuk aspek pendahuluan, 90,63 \% untuk aspek media video, 87,5 \% untuk aspek media audio, 87,5 $\%$ untuk aspek operasional, dan $100 \%$ untuk aspek penutup. Dari kelima aspek diperoleh hasil akhir kelayakan media sebesar 91,13\% dengan kategori "Layak". Hasil analisis penelitian pengguna (mahasiswa) ditampilkan pada Gambar 4.

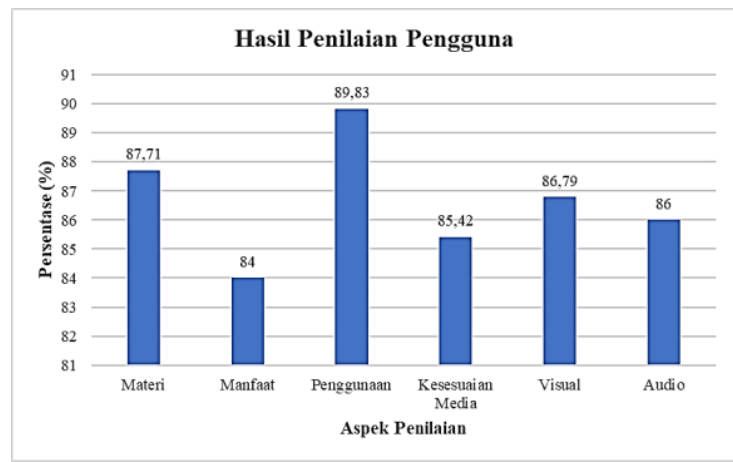

Gambar 4. Diagram Batang Hasil Kelayakan Pengguna

Dari diagram batang hasil kelayakan pengguna (Gambar 4) dapat dijelaskan bahwa hasil kelayakan oleh pengguna sebesar 3,51 untuk aspek materi, 3,36 untuk aspek manfaat, 3,59 untuk aspek penggunaan, 3,42 untuk aspek kesesuaian media, 3,47 untuk aspek visual, dan 3,44 untuk aspek audio. Berdasarkan hasil analisis keenam aspek diperoleh skor rata- 
rata hasil akhir kelayakan pengguna (mahasiswa) adalah 3,46 dengan persentase $86,62 \%$ yang masuk dalam kategori kelayakan yaitu "Layak".

\section{SIMPULAN}

Berdasarkan hasil pembahasan yang dilakukan, dapat simpulkan bahwa media video tentang OpenStreetMap untuk pembuatan peta digital format shapefile menggunakan Spatial Manager pada mata kuliah Praktikum Geomatika II sesuai dengan model pengembangan 4D oleh Thiagarajan, yang terdiri dari 4 tahap yaitu 1) Tahap Define (Pendefinisian) pada pengembangan media pembelajaran ini menghasilkan kebutuhan pembelajaran tentang OpenStreetMap untuk pembuatan peta digital menggunakan Spatial Manager berupa: (1) silabus yang akan digunakan sebagai pedoman pengembangan media; (2) perumusan tujuan pembelajaran yaitu (a) mengakses web openstreetmap.org, (b) melakukan pemilihan daerah data yang akan diekstrak, (c) mengunduh data sesuai daerah yang ditentukan, dan (d) mengekstrak data unduhan menjadi format shapefile menggunakan Spatial Manager; selain itu juga diperoleh (2) karakteristik siswa; kemudian dilakukan (3) pengkajian materi Praktikum Geomatika II; (4) perangkat pembuat media; dan (5) penggunaan media. Materi dan media pengembangan video pembelajaran yang dikembangkan digunakan oleh mahasiswa semester 5 Program Studi Pendidikan Teknik Sipil dan Perencanaan FT UNY; 2) Tahap Design (Perancangan) ini terkumpul materi yang kemudian didesain dalam media pembelajaran berbasis video. Dalam media disesuaikan dengan: kondisi kelas; perancangan media pembelajaran yang meliputi: flowchart, storyboard, penataan materi dalam media yang terdiri dari tata letak (layout) yang digunakan, pembuatan skenario pembelajaran, penyusunan materi; dan divisualisasikan dengan penggunaan video. Video pembelajaran ini berupa pembuatan peta digital OpenStreetMap format shapefile menggunakan aplikasi Spatial Manager dengan format *.mp4, durasi waktu 15 menit 50 detik dan file berukuran 56,7 MB. Dalam video pembelajaran tersebut terbagi menjadi 3 pokok kerangka yaitu pembukaan, materi, dan penutup. Pada pembukaan video (menit ke 00:00-00:36) menampilkan logo UNY dan tulisan Jurusan Pendidikan Teknik Sipil dan Perencanaan Fakultas Teknik Universitas Negeri Yogyakarta, serta judul video yaitu Video Pembelajaran "OpenStreetMap untuk Pembuatan Peta Digital format shapefile menggunakan Spatial Manager". pada tampilan materi (menit ke 00:36-15:21) berisi tentang: (1) tujuan pembelajaran; (2) persiapan alat dan bahan; (3) persiapan K3; (4) perkembangan alat pemetaan; (5) langkah pokok pembuatan peta digital OSM menggunakan aplikasi Spatial Manager meliputi: pengunduhan data peta dari OSM, membuka file OSM pada aplikasi Spatial Manager, dan mengekstrak file OSM menjadi format shapefile; dan (6) kesimpulan dari video pembelajaran. Sedangkan pada tampilan penutup (menit ke 15:21-15:50) berisi tentang pesan dan ucapan terimakasih; 3) Tahap Development (Pengembangan) menghasilkan penilaian terhadap tingkat kelayakan produk media pembelajaran yang dikembangkan. Berdasarkan ahli materi media pembelajaran diperoleh hasil penilaian ahli materi sebesar 90,91 \% dan termasuk dalam kategori "Layak", sedangkan dari ahli media diperoleh nilai 
Pengembangan Video ... (Ilham/ hal. 190-196)

sebesar 91,13 \% dengan kategori "Layak". Penilaian uji kelayakan terhadap pengembangan media pembelajaran berbasis video ini juga dilakukan oleh 30 mahasiswa dengan hasil kelayakan sebesar 86,62 \% dengan kategori "Layak"; dan 4) Tahap Dissemination (Penyebarluasan) melakukan pengunggahan video pembelajaran ke dalam channel Youtube dengan url https://www.youtube.com/watch? $\mathrm{v}=\mathrm{KNinH}$ Q4EW70\&feature=youtu.be dengan judul "Video Pembelajaran OSM untuk Pembuatan Peta Digital Format Shapefile Menggunakan Spatial Manager" serta penyebaran dengan memberikan file kepada pengguna untuk proses pembelajaran.

\section{DAFTAR PUSTAKA}

Arikunto, S. (1996). Prosedur Penelitian: Suatu Pendekatan Praktik. Jakarta:PT Rineka Cipta.

Badan Pusat Statistik. (2019). Tingkat Pengangguran Terbuka (TPT). Februari BPS Jakarta. Jakarta.

Hananta, R.O. \& Sukardi, T. (2018). Pengembangan Model Media Video pada Pembelajaran Praktik Pemesinan Bubut. Jurnal Dinamika Vokasional Teknik Mesin 3(2): 121-129.

Humanitarian OpenStreetMap Team. (2015). Modul Penjaminan Kualitas Data untuk OpenStreetMap.

Mardapi, D. (2008). Teknik Penyusunan Instrumen Tes dan Nontes. Yogyakarta: Mitra Cendikia Press.

Muhariati, M. dkk. (2017). Assessing The Impact of Instructional Video Clips In The Training of Bread Production. Jurnal Pendidikan Teknologi dan Kejuruan 23 (3). Diambil pada tanggal
13 Oktober 2020, dari https://journal.uny.ac.id/index.php/jptk/ article/view/13404.

Nuryadin, R. (2005). Panduan Menggunakan Mapserver. Bandung: Informatika.

Opencartis. (2009). Spatial Manager. Diambil pada tanggal 6 Agustus 2019, dari http://www.spatialmanager.com/.

OpenStreetMap. (2004). OpenStreetMap. Diambil pada tanggal 6 Agustus 2019, dari https://openstreetmap.org/.

Pusparisa, Y. (2019). Angka Pengangguran Lulusan Universitas Meningkat. https://katadata.co.id/infografik/2019/ 05/17/angka-pengangguran-lulusanperguruan-tinggi-meningkat. 6 Februari 2020 (08:47).

Rochmadi, S. \& Hidayat, N. (2020). Developing a learning video of the total station for building stake out. Journal of Physics: Conference Series 1456012049 doi:10.1088/17426596/1456/1/012049

Thiagarajan, S., Semmel, D.D., \& Semmelpp, M.I. (1974). Instructional Developmentfor Training Teachers of Exceptional Children. Minnesotta: U.S. Office of Education.

Umarella, S., Saimima, M.S., \& Hussein, S. (2018). Urgensi Media dalam Proses Pembelajaran. Jurnal Pendidikan Agama Islam 3(2): 237. 